\title{
Xanthomonas vasicola pv. musacearum down-regulates selected defense genes during its interaction with both resistant and susceptible banana.
}

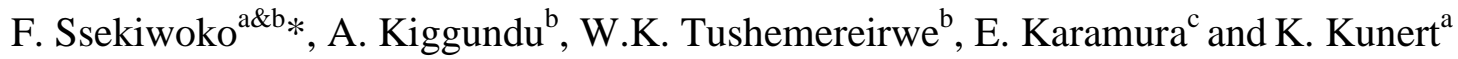 \\ ${ }^{a}$ Forestry and Agricultural Biotechnology Institute, University of Pretoria, PRETORIA, 0002, RSA \\ ${ }^{\mathrm{b}}$ National Agricultural Research Laboratories, P.O. Box 7065 Kampala, Uganda \\ ${ }^{\mathrm{c}}$ Bioversity International, Kampala Office, Plot 106, Katalima Road, Naguru, , P.O. Box 24384, Kampala, Uganda,
}

\begin{abstract}
Expression of specific R, NPR1 and PR genes was investigated to ascertain their role in the resistance of Musa balbisiana to Xanthomonas vasicola pv. musacearum (Xvm). Following inoculation, wilt symptoms developed in test plants though their incidence and severity climaxed merely at $30 \%$ and $20 \%$ respectively before recovery. Xvm was limited to the inoculated and the immediate follower leaves and its population in a 50mg tissue dropped from 3.06x107cfu at 18 days to $0 \mathrm{cfu}$ by 140 days after inoculation (DAI). In susceptible banana, it instead increased from $3.41 \times 108$ to $1.08 \times 1011 \mathrm{cfu}$ by $21 \mathrm{DAI}$ culminating in plant death. Expression of $M b N B S$, $M d N P R 1$ and PR3 sharply declined during the first 6 hours, recovering in the later stages though this did not stop later wilt symptoms developed in resistant and susceptible plants. We concluded that neither Hypersensitive response, nor Systemic Acquired Resistance nor Induced systemic resistance is the resistance mechanism for M. balbisiana against Xvm as it suppresses key genes in these pathways.
\end{abstract}

Key words: Resistance, Xanthomonas vasicola pv. musacearum and Musa balbisiana

\section{Introduction}

Banana Xanthomonas wilt disease caused by Xanthomonas vasicola pv. musacearum (Xvm) formerly Xanthomonas campestris pv. musacearum (Xcm) [1] is the most devastating disease of banana in East and Central Africa threatening livelihoods of over 80millions of people in subSaharan Africa who depend on it. The disease causes wilting of plants, premature ripening of banana fruits and all affected plants always die leading to total yield loss. All cultivated banana varieties in the region are susceptible except Musa balbisiana, a wild banana which is resistant to the disease [2]. In order to effectively exploit this genotype, it the mechanism of resistance which has not been known upto this date needs to be clearly understood.

In a typical basal resistance response, host plants use specific pattern recognition receptors (PRRs) on their cell-surfaces to detect the conserved microbe associated molecular patterns (MAMPs) such as bacterial flagellins, lipopolysaccharides, elongation factors, fungal chitin and heptaglucosides of the invading microbes [3]. This recognition triggers activation of signaltransduction cascades that turn on basal defense mechanisms such as callose and silicone deposition to reinforce the cell wall, closure of stomata, production of reactive oxygen species, transcriptional induction of pathogenesis-related genes (PR) and post-transcriptional suppression of the auxin-signalling pathway [4] among others. Some pathogens have evolved ways to directly introduce effectors into the cells using the type three secretion system (TTSS), thereby evading basal defense mechanisms. Some resistant plants however use $\mathrm{R}$ proteins to recognize the presence of these effectors inside the plant cells and set in a chain of reactions that eventually arrest the pathogen [5]. 
Normally, presence of the pathogen and the subsiquent recognition of the same or its effectors leads to an increased production of superoxide $\left(\mathrm{O}_{2}^{-}\right)$on the apoplastic face of the plasmalemma. At the same time a signal is translocated all over the plant to prepare such tissues for any eventual attack. Meanwhile, superoxide dismutase (SOD) at the apoplast rapidly converts $\mathrm{O}_{2}^{-}$to $\mathrm{H}_{2} \mathrm{O}_{2}$ which may not only affect the pathogen but also damage the plant cells. The higly abandunt peroxidases detoxfy $\mathrm{H}_{2} \mathrm{O}_{2}$ using ascorbate, as a reducing substrate through the ascorbate-glutathione cycle [6]. The detoxification reactions change the redox state of cells and this leads to monomerization of cytosolic Nonexpresor of pathogenesis related 1 protein (NPR1) which subsiquently leads to its translocation into the nucleus, interacts with transcription factors resulting in activation of various forms of antimicrobial pathogenesis related (PR) genes [7] [8] [9] [10]. This eventually confirs resistance to a broad spectrum of pathogens during establishment of systemic acquired resistance and induced systemic resistance [11] [12].

In this study therefore, changes in disease development and expression of specific R, NPR1 and PR genes were investigated to ascertain their role in the resistance of Musa balbisiana to Xanthomonas vasicola pv. musacearum.

\section{Materials and methods}

\section{Experimental setup}

A screen-house pot experiment was set up with tissue cultured banana plantlets using $M$. balbisiana and a cooking banana cultivar Nakinyika as resistant and susceptible genotypes respectively. Fourty two (42) tissue culture plants of each banana genotype were weaned in plastic pots and allowed to establish for 8 weeks. A compleatly randomised design was adopted for the trial in which the two treatments (injection with either water or Xvm) were randomly applied to 21 plants of each genotype. The Xvm inoculum of aproximately $\mathrm{X}^{8} 0^{8}$ cell per ml was prepared using one of the vilulent preserved cultures at the National Agricultural Biotechnology center Kawanda, Kampala Uganda. One tenth of a ml $(100 \mu \mathrm{L})$ of either water or Xvm as inoculum was drawn into a hypodermic syringe and then injected into the second youngest open leaf petiole of the test plants. A random sample of 3 plants for each treatment was drawn at intervals of $0 \mathrm{hrs}$, 6hrs, $72 \mathrm{hrs}$, and 14days post inoculation for RNA extraction. Later, another random sample of 3 plants for each treatment was drawn at 18, 25, 56, 90 and 150 days after inoculation for Xvm isolation.

\section{Assessment of bacterial population changes within plant tissues}

Part of the leaf petiole of the inoculated leaf (at $5 \mathrm{~cm}$ below point of inoculation) and its younger immediate follower leaf was cut, surface sterilized by washing in dilute $\mathrm{NaOCl}(1: 5)$ with water, then rinsed 3 times in sterile water and blotted dry. Its tissues were aseptically cut, weighed and suspended in sterile water $(0.5 \mathrm{~g} / \mathrm{ml}$ of water). After suspending for 15 minutes, this suspension was serially diluted 6 times, $10 \mu \mathrm{L}$ of each dilution plated on semi-selective CCA medium (Mwangi et al., 2007) and incubated at $25^{\circ} \mathrm{C}$ for 5 days.

\section{RNA extraction}

To collect a plant sample for RNA extraction, $10 \mathrm{~g}$ of the apex of the follower leaf to the inoculated leaf was cut at once with a sterile surgical blade, wrapped in a labeled aluminum foil sheet and immediately frozen in liquid nitrogen. RNA from each sample was extracted following the CTAB nucleic acid extraction protocol. Generally, $0.1 \mathrm{~g}$ of each frozen plant tissue was crushed in a separate sterile and frozen motor into a powder and $1.5 \mathrm{ml}$ of pre-warmed $\left(65^{\circ} \mathrm{C}\right)$ 
extraction buffer containing: CTAB (20g/L), NaCl (81.76g/L), PVP-40 (20g/L), Tris-HCl $(15.76 \mathrm{~g} / \mathrm{L})$, EDTA $(18.61 \mathrm{~g} / \mathrm{L})$ and $2 \% \quad \beta$-mercapto-ethernol was added. The mixture was incubated at $65^{\circ} \mathrm{C}$ for 15 mins while mixing every 2 mins by inversion after which it was centrifuged at $13000 \mathrm{rpm}$ for 5 mins. In a new sterile tube, $700 \mu \mathrm{L}$ of supernatant were transferred and cooled on ice for 2 mins after which $700 \mu \mathrm{L}$ of chloroform: isoamyl alcohol (24:1) was added and mixed by inversion. It was then centrifuged at $13000 \mathrm{rpm}$ for $5 \mathrm{mins}$ at $4^{\circ} \mathrm{C}$. The aqueous phase $(600 \mu \mathrm{L})$ was transferred to a new tube and an equal volume of phenol: chloroform: isoamyl alcohol (25: 24:1) added, mixed by inversion, then centrifuged at 13000rpm for 5 mins at $4{ }^{\circ} \mathrm{C}$. Finally $500 \mu \mathrm{L}$ of the aqueous phase was transferred to a new tube, and RNA precipitated by adding $10 \mathrm{M}$ lithium chloride to a final morality of $2.25 \mathrm{M}$ then incubated at $-20^{\circ} \mathrm{C}$ for $8 \mathrm{hrs}$. The precipitate was then collected by spinning at $13000 \mathrm{rpm}$ for 45 mins after which the supernatant was discarded. The pellet was reconstituted in water to $450 \mu 1$, then $1 / 9$ volume of $3 \mathrm{M}$ sodium acetate ( $\mathrm{Ph} \mathrm{5.2)}$ added followed by an equal volume of cold iso-propanol $\left(-20^{\circ} \mathrm{C}\right)$ and mixed by inversion. The mixture was kept at $-20^{\circ} \mathrm{C}$ overnight and then spun at $13000 \mathrm{rpm}$ for 2 mins at $4^{\circ} \mathrm{C}$. Iso-propanol was decanted and the pellet washed twice in $500 \mu \mathrm{L}$ of $70 \%$ ethanol by tapping and spinning at $13000 \mathrm{rpm}$ for $2 \mathrm{mins}$ at $4{ }^{\circ} \mathrm{C}$. The pellet was air dried at room temperature for 40 mins after which it was re-suspended in $30 \mu \mathrm{L}$ of sterile nuclease free water and stored at $-20^{\circ} \mathrm{C}$.

\section{RNA purification}

Genomic DNA traces were removed using a DNase treatment kit by Thermo scientific (EN0521) following the manufacturer's protocol. Generally, to $6 \mu \mathrm{L}$ of nuclease free water were added $1 \mu \mathrm{L}$ of $10 \mathrm{X}$ buffer, then $2 \mu \mathrm{L}$ of RNA (approximately $0.5 \mu \mathrm{g}$ ) and $1 \mu \mathrm{L}$ of DNase $\mathrm{I}(1 \mathrm{u} / \mu \mathrm{L}$ ). The resultant $10 \mu \mathrm{L}$ reaction mixture was incubated at $37^{\circ} \mathrm{C}$ for 30 mins after which $1 \mu \mathrm{L}$ of $50 \mathrm{mM}$ EDTA was added and incubated at $65^{\circ} \mathrm{C}$ for 15 mins to inhibit any further DNase I reactions. The contents were immediately chilled on ice for $1 \mathrm{~min}$, collected by brief spinning and then stored at $-20^{\circ} \mathrm{C}$ awaiting cDNA synthesis.

\section{cDNA synthesis}

cDNA was synthesed using the RevertAid ${ }^{\mathrm{TM}}$ first strand cDNA synthesis Kit (Fermentas Life Sciences) according to the manufacturer's protocol. Generally, to $8 \mu \mathrm{L}$ of nuclease free water, $3 \mu \mathrm{L}$ of pure RNA sample and $1 \mu \mathrm{L}$ of random hexamer primers $(0.2 \mu \mathrm{g} / \mu \mathrm{L})$ were added. This mixture was incubated at $65^{\circ} \mathrm{C}$ for 5 mins, then immediately chilled on ice for 5 mins and the contents were collected by brief spinning. During reverse transcription, to the primer annealed reaction mixture was added $4 \mu \mathrm{L}$ of $5 \mathrm{x}$ reaction buffer, $1 \mu \mathrm{L}$ Ribolock RNase inhibitor $(20 \mathrm{u} / \mu \mathrm{L})$, $2 \mu \mathrm{L}$ of $10 \mathrm{mM} \mathrm{dNTP}$ mix, and $1 \mu \mathrm{L}$ of Reverse transcriptase $(200 \mathrm{u} / \mu \mathrm{L})$. This mixture was incubated at $25^{\circ} \mathrm{C}$ for 5 mins after which it was further incubated at $42^{\circ} \mathrm{C}$ for $1 \mathrm{hr}$ followed by heating at $70^{\circ} \mathrm{C}$ for 5 minutes to inactivate reverse transcriptase. The contents (now cDNA) were then chilled on ice, collected by spinning and the cDNA was quantified using a nanodrop 2000 for all samples taken and was standardised to $0.08 \mu \mathrm{g} / \mu \mathrm{L}$ by dilution in sterile nuclease free water before storing at $-20^{\circ} \mathrm{C}$.

\section{Primer design}

MbNBS Primers (Forward: 5'TGCTGGTGTTGGATGATGTT3' and Reverse: 5'GGCAGGTCTTGGTAGCTCAG3') for amplifcation of genes with NBS-LRR binding sites that are typical of detecting pathogen effectors were designed. In addition, MdNPR1 primers (Forward: 5'GATAAGGCTATGGTGGAAGA3' and Reverse: 
(A)

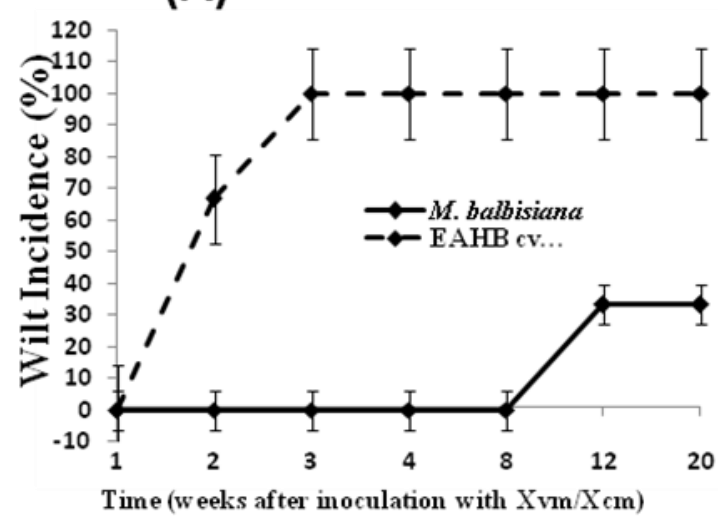

(B)

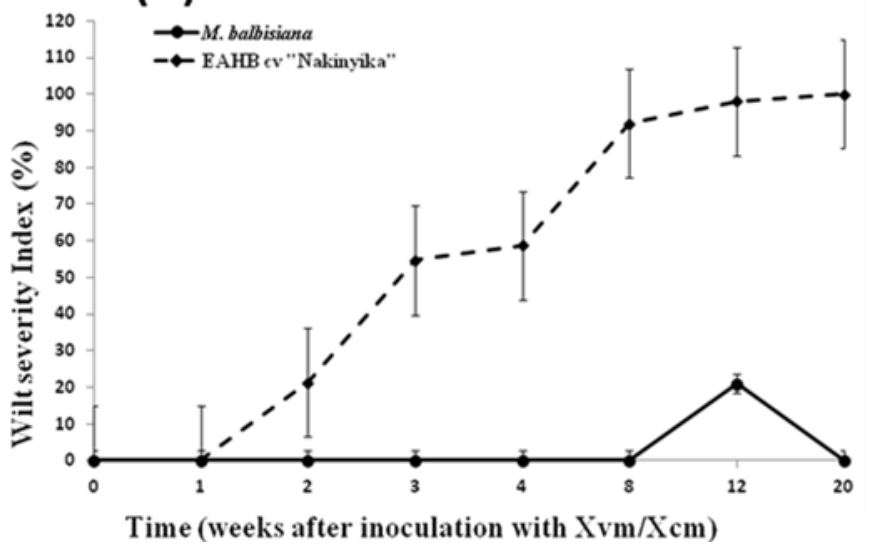

Figure 1: Change in wilt disease Incidence (A) and severity (B) over time in EAHB cv "Nakinyika" and M. balbisiana following inoculation with Xvm. 
5'CGCCCTAGTTAGTCTCCTACAT3') as designed and used by Zhao et al., (2009) for amplifcation of a banana NPR1, PR3 (Forward: 5'GGCTCTGTGGTTCTGGATGA3' and Reverse: 5'CCAACCCTCCATTGATGATG3') and a house keeping gene 25s primers (Forward: 5'ACATTGTCAGGTGGGGAGTT3' and Reverse: 5'CCTTTTGTTCCACACGAGATT3') as designed and used by Endah et al., (2008), were synthesised.

\section{Semiquantitative PCR}

For the same set of plants at a specific sampling point, cDNA was pooled prior to running PCR. A $10 \mu \mathrm{L}$ water diluted PCR mixture containing $0.05 \mu \mathrm{L}$ taq polymerase (Qiagen), $1 \mathrm{X}$ Taq buffer

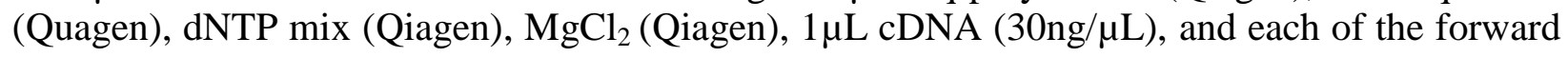
and reverse primers,) as detailed in table 1 was set up and run in a thermocycler at an initial activation temperature of $95^{\circ} \mathrm{C}$ for 5 mins, follwed by cycle denaturation at $94^{\circ} \mathrm{C}$ for $5 \mathrm{~s}$, then primer annealng for $5 \mathrm{~s}$ and cycle extenstion at $72^{\circ} \mathrm{C}$ for $10 \mathrm{~s}$ for 30 cycles, then a final extension at $72^{\circ} \mathrm{C}$ for $20 \mathrm{~s}$. The contents were electrophoresed in a $2 \%$ gel for 40 mins, stained in ethidium bromide vissualised under UV and photographed.

\section{Data collection and analysis}

\section{Wilt incidence and severity}

The number of wilted plants was expressed as a percentage of the total number of inoculated plants (Incidence). In addition, the sums of the individual proportion of wilted number of leaves to the total number leaves per plant were expressed as the percentage of the total number of plants (Severity).

\section{Bacterial population changes in planta}

The number of colonies on each plate was counted, then used to estimate the bacterial load in the original plant tissue for each plant before dilution. The mean population for the plants at a particular sampling interval was estimated and the significance of their differences estimated using SAS v9 package

\section{Changes in expression levels of selected candidate genes}

Data on expression of specific genes was captured as band intensity differences on the agarose gels. This band intensity difference was converted into numerical data using GelQuantNET software. Intensities of the housekeeping $25 \mathrm{~S}$ were standardized and factorial differences were used to estimate intensity values for targets genes. The corrected band intensity values for the target genes were log transformed and analyzed using SAS version 9. Mean band intensity due to Xvm relative to basal intensity was expressed as a ratio of band intensity due to water relative to basal intensity. The resultant ratios at a particular sampling point were plotted as Log10 ratio of relative expression against time after inoculation.

\section{Results}

\section{Wilt incidence and severity}

Wilt incidence (fig 1A) and severity (fig 1B) was noted to change over time after inoculation. In the susceptible EAHB cv "Nakinyika" wilt incidence quickly rose from 0\% to 68\% within 14 
Table 1. Primer sequences and their optimum working conditions

\begin{tabular}{|c|c|c|c|c|c|}
\hline \multirow{2}{*}{$\begin{array}{l}\text { Primer } \\
\text { name }\end{array}$} & \multirow[t]{2}{*}{ Primer sequence } & \multicolumn{3}{|c|}{ Working concentration } & \multirow{2}{*}{$\begin{array}{l}\text { Annealing } \\
\text { temparature }\end{array}$} \\
\hline & & Primer & dNTPs & $\mathbf{M g C l}_{2}$ & \\
\hline $25 \mathrm{~s}$ & F: ACATTGTCAGGTGGGGAGTT & $0.15 \mu \mathrm{M}$ & $0.2 \mathrm{mM}$ & $1.5 \mathrm{mM}$ & $57^{\circ} \mathrm{C}$ \\
\hline & R: CCTTTTGTTCCACACGAGATT & & & & \\
\hline MbNBS & $\begin{array}{l}\text { F: TGCTGGTGTTGGATGATGTT } \\
\text { R: GGCAGGTCTTGGTAGCTCAG }\end{array}$ & $0.3 \mu \mathrm{M}$ & $0.2 \mathrm{mM}$ & $1.5 \mathrm{mM}$ & $62^{\circ} \mathrm{C}$ \\
\hline MdNPR1 & $\begin{array}{l}\text { F: GATAAGGCTATGGTGGAAGA } \\
\text { R: CGCCCTAGTTAGTCTCCTACAT }\end{array}$ & $0.1 \mu \mathrm{M}$ & $0.4 \mathrm{mM}$ & $4 \mathrm{mM}$ & $55^{\circ} \mathrm{C}$ \\
\hline PR3 & $\begin{array}{l}\text { F: GGCTCTGTGGTTCTGGATGA } \\
\text { R: CCAACCCTCCATTGATGATG }\end{array}$ & $0.1 \mu \mathrm{M}$ & $0.4 \mathrm{mM}$ & $4 \mathrm{mM}$ & $60^{\circ} \mathrm{C}$ \\
\hline
\end{tabular}


Table 2: Relative average No. of $X v m$ cells recovered from the tissue $(50 \mathrm{mg})$ of $M$. balbisiana and EAHB cv "Nakinyika" at various days after inoculation (DAI) with Xvm.

\begin{tabular}{lcc}
\hline DAI & M. balbisiana & EAHB cv "Nakinyika" \\
\hline 18 & $3.06 \times 10^{7}$ & $3.55 \times 10^{8}$ \\
25 & $2.23 \times 10^{6}$ & $1.08 \times 10^{11}$ \\
56 & $8.7 \times 10^{5}$ & $\mathrm{a}$ \\
90 & $1.5 \times 10^{4}$ & $\mathrm{a}$ \\
150 & 0 & $\mathrm{a}$ \\
\hline $\mathrm{a}=$ Dead plant due to Xvm infection
\end{tabular}


days after inoculation and by the 21 days, it had reached $100 \%$. Similarly, severity of leaf wilting rose from $0 \%$ to $21 \%$ within 14 days and by 25 days after inoculation it had risen to $92 \%$. By the 56 days, all plants had died. In the resistant $M$. balbisiana on the other hand, wilt symptoms delayed and were only observed 70 days after inoculation and by the 84 days, leaf wilt incidence had only risen to $33 \%$ at which it remained even up to 140 days after inoculation. Similarly, leaf wilt severity remained at $0 \%$ for 56 days after which it rose to about $20 \%$ by the 84 days before dropping to $0 \%$ by 140 days.

\section{Trends in Xvm proliferation and migration in planta}

Xvm population in plant tissues was observed to change over the days after inoculation (Table 2). In the susceptible EAHB cv "Nakinyika", Xvm multiplied and migrated from the inoculated leaf to other leaves such that it was detectable by 18 days after inoculation. Xvm multiplication continued such that by 25 days after inoculation its population had reached $1.08 \times 10^{11}$ cells per $50 \mathrm{mg}$ of plant tissue. Subsequent death and rotting of tissues could not allow recovery of any Xvm by 56 days after inoculation. In resistant $M$. balbisiana, Xvm was also detectable by 18 days at $3.06 \times 10^{7}$ cells per $50 \mathrm{mg}$ of plant tissue. After then, it found to be continually reducing such that by 56 days it was $8.7 \times 10^{5}$ cells per $50 \mathrm{mg}$ of plant tissue. By 90 days after inoculation, $X v m$ had migrated to the follower leaves though its population was only $1.5 \times 10^{4}$ cells per $50 \mathrm{mg}$ of plant tissue. By 140 days after inoculation, it was not detectable anymore in $M$. balbisiana tissues.

\section{Changes in the expression levels of selected defence related gene}

An analysis of genes deep down in the defence pathways showed that expression levels of the PR3 gene sharply declined below basal levels in the first 6hrs after inoculation of both resistant and susceptible banana with Xvm (fig2A). In the next period up to $72 \mathrm{hrs}$ after inoculation, its expression sharply increased significantly above the basal levels in the resistant before declining back to basal levels at 14 days after inoculation. Its expression however remained significantly lower than basal levels in the susceptible plant till 14 days after inoculation. Initial decline in the expression level of PR3 suggested down regulation of the gene during the initial stages of Xvm infection of banana. Further inquiry into the possibility of down regulation of this gene showed that there was a sharp decline in the expression of MdNPRI (one of the genes high in the NPR1PR defence pathway) below basal levels in the first 6 hours after inoculation in both the resistant and susceptible banana. In the next period up to $72 \mathrm{hrs}$ after inoculation, its expression also sharply increased significantly above the basal levels in the resistant before declining back towards basal levels by 14 days after inoculation. Similarly, in the susceptible plant expression of MdNPRI also increased after $72 \mathrm{hrs}$ and went back to basal levels by 14 days except that this increase was gradual (fig2B).

Further investigations revealed that the expression levels of a putative disease resistance gene with typical NBS-LRR domains, $(M b N B S)$ significantly declined sharply below basal levels in the first $6 \mathrm{hrs}$ after inoculation of both resistant and susceptible banana with Xvm. In the next period up to $72 \mathrm{hrs}$ after inoculation, its expression also sharply increased significantly above the basal levels in the resistant before declining back towards basal levels by 14 days after inoculation. In the susceptible plant however, its expression gradually increased but remained 

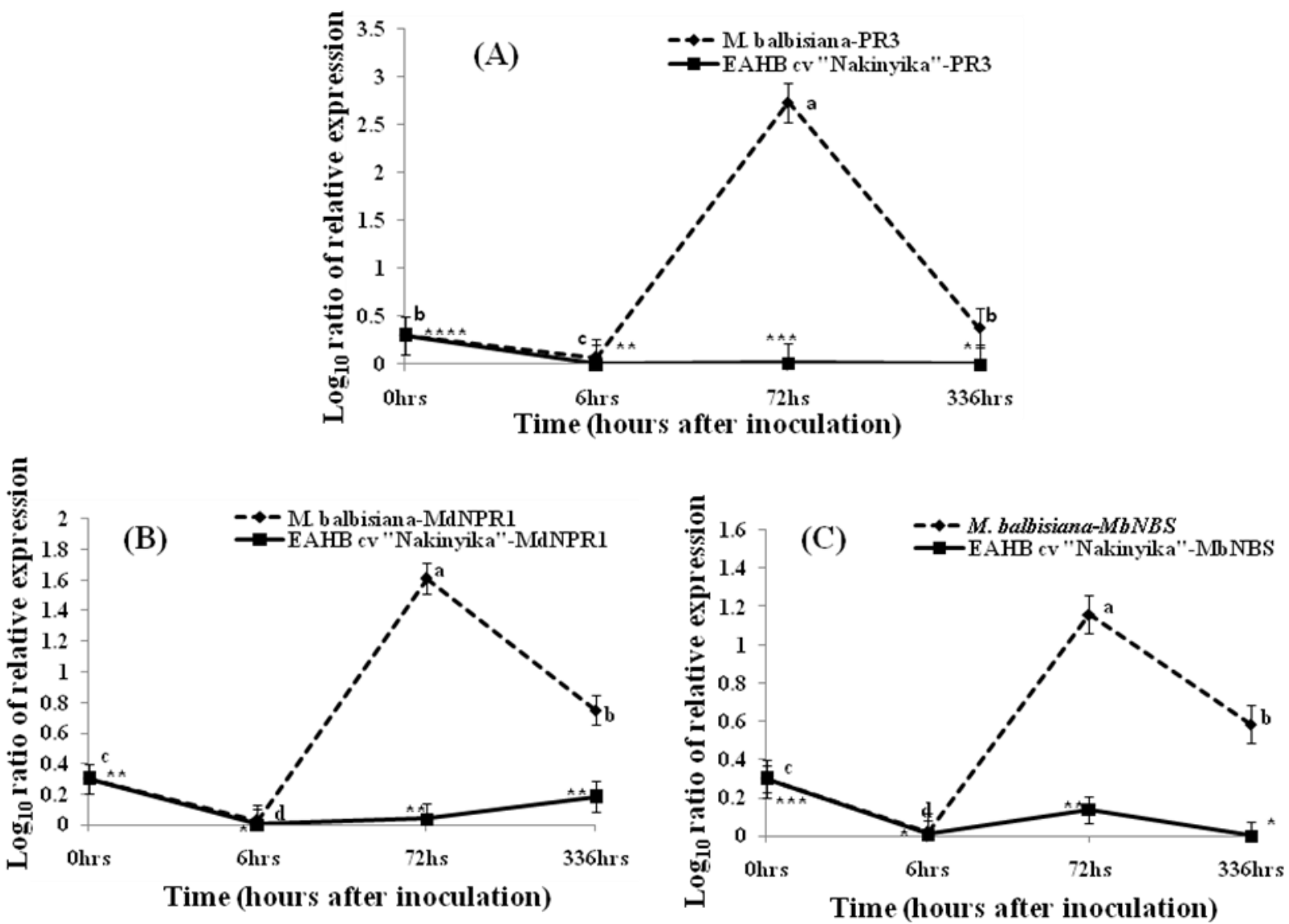

Figure 2: Relative expression levels of selected genes (A) PR3, (B) $M d N P R 1$ and (C) MbNBS in the banana defense pathway following inoculation of $M$. balbisiana and EAHB cv "Nakinyika" with the banana Xanthomonas wilt pathogen (Xvm). 
significantly lower than basal levels and had not recovered to basal levels by 14 days after inoculation (fig3C).

\section{Discussion}

The delayed symptom expression (10 weeks after inoculation), low wilt incidence and severity in M. balbsiana (which only climaxed at $20 \%$ before dropping back to $0 \%$ ) coupled with reduced multiplication and limited migration of Xvm within the plant tissues and the subsequent clearance from tissues suggests that $M$. balbisiana is resistant. Low bacterial population density to initiate infection (quorum sensing), presence of various plant defensive compounds such as phenolics, phytolexins and plant resistance proteins (including pathogenesis related proteins) are reported to delay disease expression and cause long incubation and latent periods [13] [14] through interference of the expression system of virulence factors [15] and direct killing of pathogens [16]. However, quorum sensing cannot explain the delayed symptom expression in $M$. balbisiana as at the time when symptoms were observed, the bacterial density in plant tissues was much lower than before symptom development. Other mechanisms were responsible for the resistance reaction. In a typical active defense response, tissues around the point of attack normally undergo a rapid programmed cell death termed hypersensitive response (HR) killing the pathogen within and conferring resistance to hosts. However, whole wilting of several leaves as observed in this resistant type were not typical of HR and this is not the resistance mechanism at play. A molecular dissection of the NPR1-PR defense pathway revealed some interesting findings where expression levels of some candidate genes varied over time after inoculation with $\mathrm{Xvm}$. Firstly, while there was a general increase in the expression levels of $P R 3$ in both water and Xvm treated plants, the increase was greater in the water treated than the Xvm treated plants in the first 6hrs following inoculation resulting an overall initial reduction in the expression of $P R 3$ in both the resistant and the susceptible genotypes. While this observation is in part supported by a fact that like other pathogenesis related genes, $P R 3$ is generally stress induced, with its expression levels expected to be elevated under wounding and Xvm inoculation, it in part contradicted finding of Endah [17] where there was an overall increase in the expression of $P R 3$ in Xvm susceptible plants. The overall reduced expression of $P R 3$ could probably explain development of wilt disease in both resistant and susceptible banana genotypes. Further, since $P R 3$ gene product is an antimicrobial chitinase, this finding could mean that later recovery of expression levels of this gene to and above basal levels in the susceptible and resistant respectively could be responsible for the resistance response in the resistant. However we have often noted that elevated levels of $P R 3$ do not necessarily bring about resistance as was previously shown in Cavendish banana cultivar GCTCV-218 following Xvm infection [17]. More over our findings show that $M$. balbisiana developed disease symptoms 10 weeks after inoculation (a period way after 14 days when $P R 3$ levels were back to basal levels) suggesting that $P R 3$ could not have been responsible for the observed resistance response in M. balbisiana. It could however be responsible for the delayed symptoms. Our findings further clearly show that regardless of the host resistance status, there is a general decline in the expression of PR3 below basal levels in the early stages of infection suggesting that Xvm has an overall effect of down regulating this gene in $M$. balbisiana and the EAHB cv "Nakinyika" alike.

In addition, the expression of an upstream NPR1 gene (MdNPRI) was consistent with the expression of $P R 3$ where it was also initially suppressed following Xvm infection. NPR1 is a known molecular switch that activates various forms of antimicrobial pathogenesis related $(P R)$ 
genes [7] [8] [9] [10] leading to establishment of systemic acquired resistance and induced systemic resistance [11] [12]. Its initial repression would lead to repression of $P R$ genes and later induction would also lead to $P R$ induction. Indeed this is what was exactly observed in this study where MdNPRI expression pattern was consistent with PR3 expression pattern. MdNPRI expression has already been shown to be induced by an array of elicitors including SA and FOC treatment in some banana cultivars [18]. Since NPRl is normally induced in response to different abiotic and biotic stress factors, it would also be expected to be induced by Xvm. Our finding that its expression is repressed in the early stages of infection before subsequent induction towards and above basal expression levels in the susceptible and resistant banana respectively suggests that Xvm inoculation also causes down regulation of this gene. If this is true, it would also mean that the plant is crippled in its ability to set up SAR and ISR during attack from Xvm. Indeed both the resistant and susceptible banana develop Xanthomonas wilt disease symptoms following Xvm inoculation. Since these defence responses depend on successful recognition of pathogens and or their effectors followed by signal transduction, initial repression of the downstream genes (NPRI and $P R$ ) could be a result of either a failed signal transduction system or a failed pathogen recognition system by the host plant.

The NBS-LRR domains of $M b N B S$ are characteristic of $\mathrm{R}$ genes that recognise and bind specific pathogen effectors setting in HR and SAR [19] [20] [21]. Genome wide sequence data for Xvm predicted this pathogen to use type three secretion effectors during host infection [22]. Work in our laboratory has already shown that Xvm expressed $\mathrm{HrpF}$ (an indispensible gene for establishment of the type three secretion system) during infection of banana. Pathogen effectors are known to variously suppress host defence mechanisms [23] [24]. Repression of $M b N B S$ below basal levels in the early hours following inoculation with Xvm therefore suggests that this pathogen causes its down regulation to evade detection (of its effectors). Where as its expression is induced in the subsequent period up to $72 \mathrm{hrs}$ post inoculation especially in the resistant banana leading to induction of $M d N P R 1$ and subsequently $P R 3$, it seems rather late and consequently plants develop wilt symptoms later .

This result has shown that both the Xanthomonas wilt resistant $M$. balbisiana and the Xanthomonas wilt susceptible EAHB cv. "Nakinyika" are disabled in their ability to actively defend themselves against Xvm infection. It appears that this success on the pathogen side starts when the plants detection system is disabled. Subsequently downstream reactions are also affected and the result of this would be disease development. Indeed our finding show that Xvm attempts to multiply and migrate to distant tissues in both the resistant and susceptible banana resulting in disease as observed in this study. Despite the success in disenabling of the host banana detection system and related downstream reactions, it is not clearly known why Xvm did not sustainably establish in $M$. balbisiana in which its multiplication and migration was slowed and subsequently cleared from host tissues. Other than the HR mediated disease resistance response and the pathogenesis related proteins, various phenolic compounds have also been reported to be antimicrobial affecting the multiplication and migration of bacteria in planta [16]. The role of various phenolic compounds from M. balbisiana on the multiplication of Xvm are subject for future studies. 


\section{Acknowldegements}

This work has been accomplished with support from the Government of Uganda and Bioversity international with guidance from the University of Pretoria.

\section{References}

[1] Aritua V, Parkinson N, Thwaites R, Heeney J V, Jones D R, Tushemereirwe W, ... Smith J. (2007). Characterization of the Xanthomonas sp. causing wilt of enset and banana and its proposed reclassification as a strain of X. vasicola. Plant Pathology, 57, 170-177. doi:10.1111/j.1365-3059.2007.01687.x

[2] Ssekiwoko F, Batte M, Tushemereirwe W \& Ragama PE \& Kumakech A. (2006). Reaction of Banana Germplasm to Inoculation with Xanthomonas campestris pv. musacearum. African Crop Science Journal, 14(2), 151-155.

[3] D A \& Takemoto D. (2004). Plant innate immunity - direct and indirect recognition of general and specific pathogen-associated molecules. Current Opinion in Immunology, 16(1), 48-62. doi:10.1016/j.coi.2003.11.016

[4] Nicaise V, Roux M \& Zipfel C. (2009). Recent advances in PAMP-triggered immunity against bacteria: pattern recognition receptors watch over and raise the alarm. Plant Physiology, 150(4), 1638-47. doi:10.1104/pp.109.139709

[5] Gu K, Yang B, Tian D, Wu L, Wang D, Sreekala C, ... Yin Z. (2005). R gene expression induced by a type-III effector triggers disease resistance in rice. Nature, 435(7045), 1122-5. doi:10.1038/nature03630

[6] Noctor G \& Foyer C H. (1998). ASCORBATE AND GLUTATHIONE: Keeping Active Oxygen Under Control. Annual Review of Plant Physiology and Plant Molecular Biology, 49, 249-279. doi:10.1146/annurev.arplant.49.1.249

[7] Cao H, Bowling SA, Gordon A S, \& Dong X. (1994). Characterization of an Arabidopsis Mutant That Is Nonresponsive to Inducers of Systemic Acquired Resistance. The Plant Cell, 6(11), 1583-1592. doi:10.1105/tpc.6.11.1583

[8] Foyer C H, \& Noctor G. (2011). Ascorbate and glutathione: the heart of the redox hub. Plant Physiology, 155(1), 2-18. doi:10.1104/pp.110.167569

[9] Mou Z, Fan W \& Dong X. (2003). Inducers of plant systemic acquired resistance regulate NPR1 function through redox changes. Cell, 113(7), 935-44. Retrieved from http://www.ncbi.nlm.nih.gov/pubmed/12837250

[10] Shi Z, Maximova S N, Liu Y, Verica J \& Guiltinan M J. (2010). Functional analysis of the Theobroma cacao NPR1 gene in Arabidopsis. BMC Plant Biology, 10(1), 248. doi:10.1186/1471-2229-10-248 
[11] Pieterse C M J \& Van Loon LC. (2004). NPR1: the spider in the web of induced resistance signaling pathways. Current Opinion in Plant Biology, 7(4), 456-64. doi:10.1016/j.pbi.2004.05.006

[12] Wally O, Jayaraj J \& Punja Z K. (2009). Broad-spectrum disease resistance to necrotrophic and biotrophic pathogens in transgenic carrots (Daucus carota L.) expressing an Arabidopsis NPR1 gene. Planta, 231(1), 131-41. doi:10.1007/s00425-009-1031-2

[13] Loh J, Pierson E A, Pierson L S, Stacey G \& Chatterjee A. (2002). Quorum sensing in plant-associated bacteria. Current Opinion in Plant Biology, 5(4), 285-290. doi:10.1016/S1369-5266(02)00274-1

[14] Von Bodman S B, Bauer W D \& Coplin D L. (2003). Quorum sensing in plant-pathogenic bacteria. Annual Review of Phytopathology, 41, 455-82. doi:10.1146/annurev.phyto.41.052002.095652

[15] Li Y, Peng Q, Selimi D, Wang Q, Charkowski A O, Chen X \& Yang C-H. (2009). The plant phenolic compound p-coumaric acid represses gene expression in the Dickeya dadantii type III secretion system. Applied and Environmental Microbiology, 75(5), 1223-8. doi:10.1128/AEM.02015-08

[16] Maddox C E, Laur L M \& Tian L. (2010). Antibacterial activity of phenolic compounds against the phytopathogen Xylella fastidiosa. Current Microbiology, 60(1), 53-8. doi:10.1007/s00284-009-9501-0

[17] Endah R, Coutinho T, \& Chikwamba R. (2010). Xanthomonas campestris pv musacearum induces sequential expression of two NPR1 like genes in banana. In Aspects Appl. Biol. 96, Agriculture: Africa's "Engine for growth"- Plant science and biotechnology holds the key (pp. 325-330).

[18] Zhao J.-T, Huang X, Chen Y.-P, Chen Y.-F \& Huang X.-L. (2008). Molecular Cloning and Characterization of an Ortholog of NPR1 Gene from Dongguan Dajiao (Musa spp. ABB). Plant Molecular Biology Reporter, 27(3), 243-249. doi:10.1007/s11105-008-0074-z

[19] Marone D, Russo M A, Laidò G, De Leonardis A M \& Mastrangelo A M. (2013). Plant Nucleotide Binding Site-Leucine-Rich Repeat (NBS-LRR) Genes: Active Guardians in Host Defense Responses. International Journal of Molecular Sciences, 14(4), 7302-26. doi:10.3390/ijms14047302

[20] Wang X, Chen J, Yang Y, Zhou J, Qiu Y, Yu C, ... Chen J. (2012). Characterization of a Novel NBS-LRR Gene Involved in Bacterial Blight Resistance in Rice. Plant Molecular Biology Reporter, 31(3), 649-656. doi:10.1007/s11105-012-0537-0

[21] Yue J.-X, Meyers B C, Chen J.-Q, Tian D \& Yang S. (2012). Tracing the origin and evolutionary history of plant nucleotide-binding site-leucine-rich repeat (NBS-LRR) genes. The New Phytologist, 193(4), 1049-63. doi:10.1111/j.1469-8137.2011.04006.x 
[22] Studholme D J, Kemen E, MacLean D, Schornack S, Aritua V, Thwaites R, ... Jones J D G. (2010). Genome-wide sequencing data reveals virulence factors implicated in banana Xanthomonas wilt. FEMS Microbiology Letters, 310(2), 182-92. doi:10.1111/j.15746968.2010.02065.x

[23] Cheong H, Kim C.-Y, Jeon J.-S, Lee B.-M, Sun Moon J, \& Hwang I. (2013). Xanthomonas oryzae pv. oryzae type III effector XopN targets OsVOZ2 and a putative thiamine synthase as a virulence factor in rice. PloS One, 8(9), e73346. doi:10.1371/journal.pone.0073346

[24] Üstün S, Bartetzko V \& Börnke F. (2013). The Xanthomonas campestris type III effector XopJ targets the host cell proteasome to suppress salicylic-acid mediated plant defence. PLoS Pathogens, 9(6), e1003427. doi:10.1371/journal.ppat.1003427 


\section{Appendix A. Supplementary data}

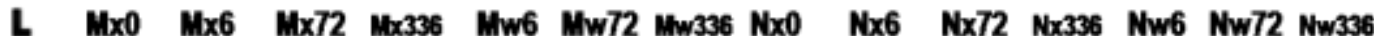

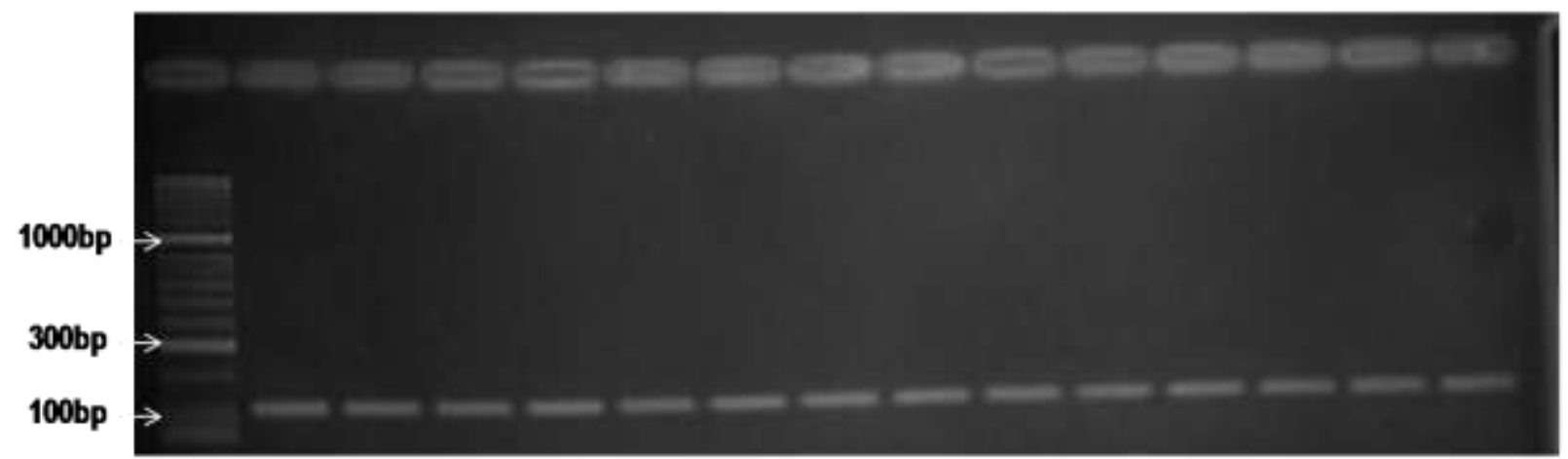

Figure 3: Expression profile of gene 25S rRNA in M. balbisiana and EAHB cv "Nakinyika" inoculated with Xvm and water. $\mathrm{L}$ indicates molecular ladder; $\mathrm{Mx}$ indicates $M$. balbisiana inoculated with Xvm, Mw indicates M. balbisiana inoculated with water; Nx indicates EAHB cv "Nakinyika" inoculated with Xvm, Nw indicates EAHB cv "Nakinyika" inoculated with water. $0,6,72$, and 336 indicates the time course of sampling (hours post inoculation).

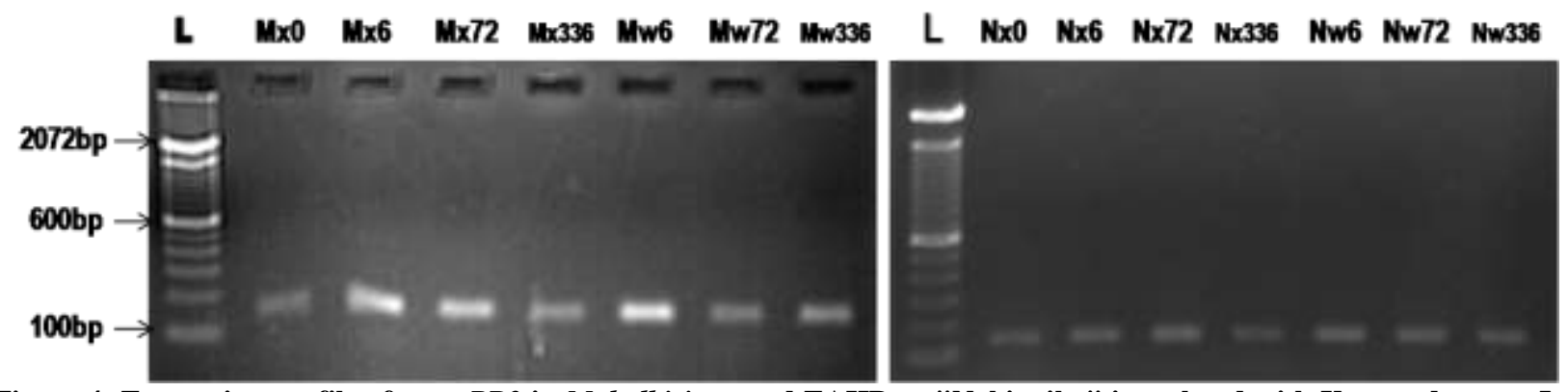

Figure 4: Expression profile of gene PR3 in M. balbisiana and EAHB cv "Nakinyika" inoculated with Xvm and water. L indicates molecular ladder; Mx indicates M. balbisiana inoculated with Xvm, Mw indicates M. balbisiana inoculated with water; Nx indicates EAHB cv "Nakinyika" inoculated with Xvm, Nw indicates EAHB cv "Nakinyika" inoculated with water. $0,6,72$, and 336 indicates the time course of sampling (hours post inoculation).
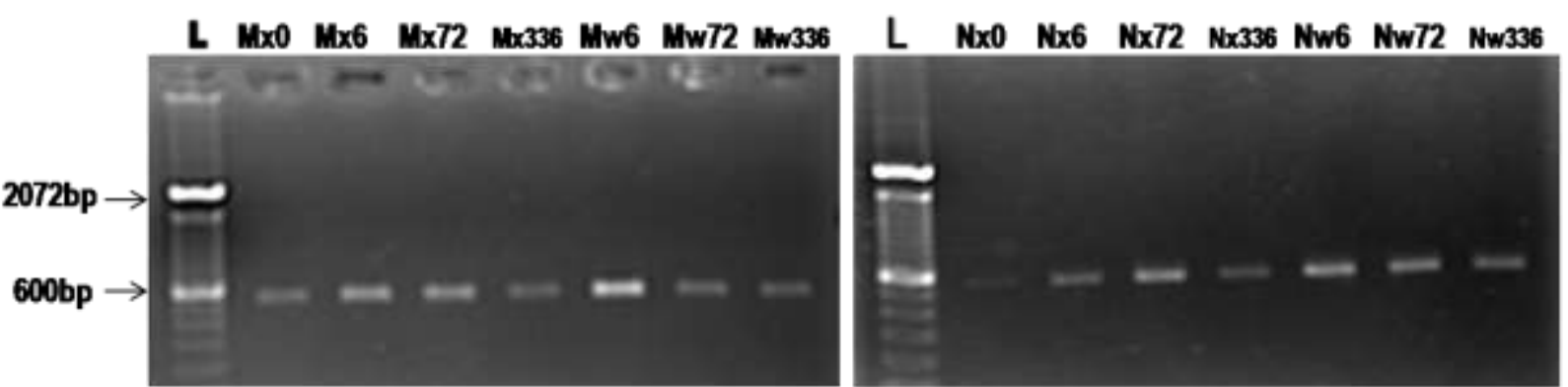

Figure 5: Expression profile of gene MdNPRI in M. balbisiana and EAHB cv "Nakinyika" inoculated with Xvm and water. $\mathrm{L}$ indicates molecular ladder; Mx indicates $M$. balbisiana inoculated with Xvm, Mw indicates M. balbisiana inoculated with water; Nx indicates EAHB cv "Nakinyika" inoculated with Xvm, Nw indicates EAHB cv "Nakinyika" inoculated with water. $0,6,72$, and 336 indicates the time course of sampling (hours post inoculation). 

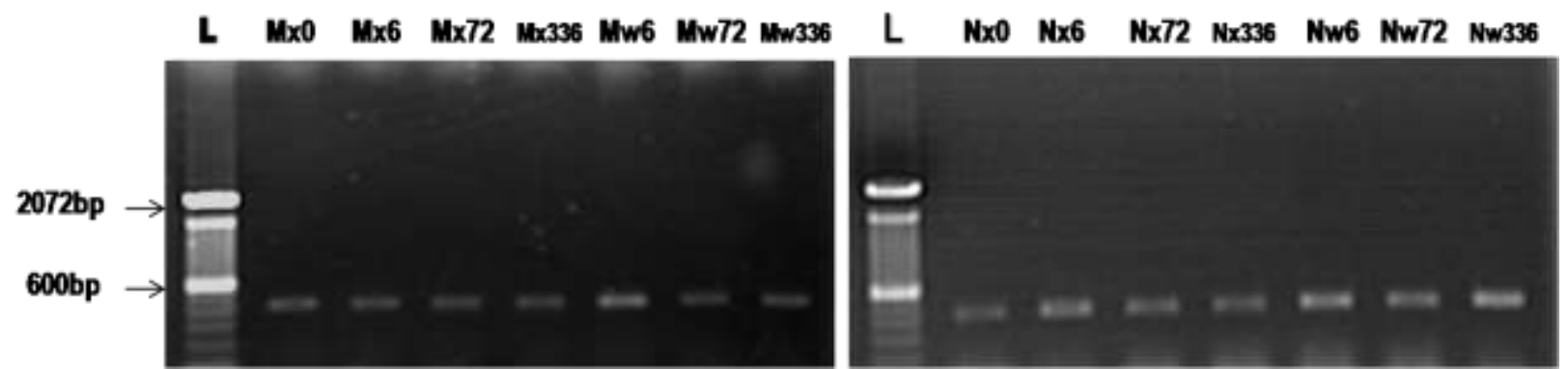

Figure 6: Expression profile of gene $M b N B S$ in $M$. balbisiana and EAHB cv "Nakinyika" inoculated with Xvm and water. $\mathrm{L}$ indicates molecular ladder; Mx indicates $M$. balbisiana inoculated with Xvm, Mw indicates M. balbisiana inoculated with water; Nx indicates EAHB cv "Nakinyika" inoculated with Xvm, Nw indicates EAHB cv "Nakinyika" inoculated with water. $0,6,72$, and 336 indicates the time course of sampling (hours post inoculation). 